\title{
Flagging a species as threatened: the case of Eptesicus taddeii, an endemic bat from the Brazilian Atlantic Forest
}

\author{
Enrico Bernard ${ }^{1,4}$, Jorge Luiz do Nascimento ${ }^{2}$ \& Ludmilla Moura de Souza Aguiar ${ }^{3}$ \\ ${ }^{1}$ Departamento de Zoologia, Universidade Federal de Pernambuco - UFPE, \\ Rua Nelson Chaves, s/n, Cidade Universitária, CEP 50670-420, Recife, PE, Brasil \\ ${ }^{2}$ Instituto Chico Mendes de Conservação da Biodiversidade - ICMBio, Reserva Biológica Guaribas - RBG, \\ PB 071, Km 01, Estrada para Jacaraú, Zona Rural, CEP 58280-000, Mamanguape, PB, Brasil \\ ${ }^{3}$ Departamento de Zoologia, Instituto de Ciências Biológicas, Universidade de Brasília - UnB, \\ Campus Darcy Ribeiro, CEP 70910-900, Brasília, DF, Brasil \\ ${ }^{4}$ Corresponding author: Enrico Bernard, e-mail: enricob2@gmail.com
}

BERNARD, E., NASCIMENTO, J.L. \& AGUIAR, L.M.S. Flagging a species as threatened: the case of Eptesicus taddeii, an endemic bat from the Brazilian Atlantic Forest. Biota Neotrop. 13(2): http://www. biotaneotropica.org.br/v13n2/en/abstract?short-communication+bn01413022013

\begin{abstract}
The IUCN Red List is an important conservation tool. Although its criteria are used worldwide, in most cases the classification process per se is restricted to a group of experts with restricted or no participation of the general public. This may raise concerns from final Red List users, which, without knowing the data or procedures adopted by the experts, may argue on the outcomes, final classification adopted, or the overall use of the lists. IUCN recommends that all assessments must be backed up by data and justifications, making them as accurate and transparent as possible. We describe here the assessment of Eptesicus taddeii, a bat species endemic to the southern Atlantic Forest of Brazil, indicating how and why the species was flagged as Vulnerable - B2ab(i, ii, iii) during its national evaluation.
\end{abstract}

Keywords: Chiroptera, conservation policy, endangered species, IUCN, Red List.

BERNARD, E., NASCIMENTO, J.L. \& AGUIAR, L.M.S. Classificando uma espécie como ameaçada: o caso de Eptesicus taddeii, um morcego endêmico da Mata Atlântica Brasileira. Biota Neotrop. 13(2): http://www. biotaneotropica.org.br/v13n2/pt/abstract?short-communication+bn01413022013

Resumo: A Lista Vermelha da IUCN é uma importante ferramenta conservacionista. Embora seus critérios sejam mundialmente usados, na maior parte dos casos o processo de classificação per se é restrito a um grupo de especialistas, com pouca ou nenhuma participação do público em geral. Isto pode gerar inquietações por parte dos usuários finais da Lista Vermelha, os quais, desconhecendo os dados ou procedimentos adotados pelos especialistas, podem questionar as classificações, o resultado final da lista, ou mesmo o uso da lista em si. A IUCN recomenda que todas as avaliações tenham suporte de dados e justificativas, tornando este processo o mais correto e transparente o possível. Descrevemos aqui o processo de classificação de Eptesicus taddeii, um morcego endêmico da porção sul da Mata Atlântica brasileira, indicando como e porque a espécie foi classificada como Vulnerável - B2a,b(i, ii, iii) durante sua avaliação nacional.

Palavras-chave: Chiroptera, politicas de conservação, espécies ameaçadas, IUCN, Listas Vermelhas. 


\section{Introduction}

Evaluating species conservation status is an important tool for establishing conservation priorities (Margules \& Pressey 2000). Since 1966 the World Conservation Union (IUCN) has evaluated species' conservation status worldwide, and today the IUCN Red Lists are broadly accepted and adopted in conservation biology, both for research, information or policy making (e.g. Collar 1996, Akçakaya et al. 2000, Margules \& Pressey 2000, Rodrigues et al. 2004, 2006, Butchart et al. 2005, Miller et al. 2007). Red lists attend to different purposes, indicating extinction risk, rarity, cultural importance, conservation value, population decline, conservation priorities, international responsibility for protection, or a combination of several of these factors, at local, regional and global scales (Miller et al. 2007), and should, therefore, be constantly improved.

The IUCN Red List Categories and Criteria were first published in 1994 following six years of research and consultation, and a posterior revised version (currently 3.1) was published seven years later (International... 2001). Although such criteria were developed to improve objectivity and transparency in assessing the conservation status of species, in most cases the classification process per se is restricted to a group of experts with restricted or no participation of the general public. The technical aspects involved with the classification of a species as threatened or not require that evaluators have a background not only in the biological and ecological aspects of the species, but also on the guidelines, the definitions of the many terms used in the criteria, and how the criteria should be applied. Therefore, the more restricted aspect of such process could be partially justified. However, this may raise concerns from final red list users, which, without knowing the data or procedures adopted by the experts, may argue the outcomes, final classification adopted, or the overall use of the lists (Hilton-Taylor et al. 2000, Possingham et al. 2002, Miller et al. 2006).

With the objective of facilitating the exchange of information between national and global red list authorities, IUCN recommends that all assessments should follow the global minimum documentation standards (International... 2011). Assessments must be backed up by data, justifications, sources and estimates of uncertainty and data quality, making them as accurate and transparent as possible. In June 2012, during a workshop to evaluate the conservation status of the Brazilian bat fauna promoted by the Instituto Chico Mendes de Conservação da Biodiversidade (ICMBio), we evaluated the status of Eptesicus taddeii, a species endemic to the southern Atlantic Forest of Brazil, applying the criteria adopted by the IUCN Red List of Threatened Species (International... 2011). In order to make this process transparent and accessible for the people interested on it, we describe here the results of such assessment, indicating how and why the species was flagged as threatened at a national level.

\section{Material and Methods}

The species - Eptesicus taddeii (Chiroptera: Vespertilionidae) is a medium size $(\sim 5-9 \mathrm{~g}$, forearm 41-48 mm), reddish-furred bat described in 2006 (Miranda et al. 2006), based on specimens from two localities in eastern Paraná, one locality in the northern part of Santa Catarina, and one locality in southern São Paulo state, all in the southern cone of Brazil. Posterior studies extended the known distribution of E. taddeii to 12 localities, with the northernmost record in Botucatu (São Paulo), and the southernmost record in São José dos Ausentes (Rio Grande do Sul) (see Miranda et al. 2010). Four other species of Eptesicus occurs in Brazil: E. chiriquinus, E.diminutus, $E$. brasiliensis and $E$. furinalis, with the latter two already recorded in simpatry with E. taddeii. Although there is no data on its biology, as it congeners this species is an exclusive insectivore. Based on its known distribution, E. taddeii is currently restricted to the Atlantic Forest lato sensu, with most of the records in mixed araucaria forest, two records in semi-deciduous seasonal forest (Londrina, PR and Botucatu, SP, this one in the transition between cerrado and Atlantic Forest), and a single record in Atlantic forest strictu sensu (Iguape, SP) (Miranda et al. 2010). The species has been recorded in three protected areas: Parque Estadual de Campinhos (PEC-337 ha), Área de Proteção Ambiental Estadual da Escarpa Devoniana (APAED-392,633 ha), both in PR, and Parque Estadual Turístico do Alto Ribeira (PETAR-36,000 ha), in SP.

IUCN Red List classification - We used the IUCN Red List Categories and Criteria Version 3.1 (see International... 2001), which is based on five main criteria: A) Declining population (past, present and/or projected); B) Geographic range size, and fragmentation, decline or fluctuations; C) Small population size and fragmentation, decline, or fluctuations; D) Very small population or very restricted distribution; and E) Quantitative analysis of extinction risk (e.g., Population Viability Analysis). Criterion B takes into consideration two sub-criteria: B1) Extent of occurrence (EOO), defined as the area contained within the shortest continuous imaginary boundary which can be drawn to encompass all the known, inferred or projected sites of present occurrence of a taxon, excluding cases of vagrancy; and B2) Area of occupancy (AOO), defined as the area within its 'extent of occurrence' which is occupied by a taxon, excluding cases of vagrancy. In other words, the AAO represents the area of suitable habitat currently occupied by the taxon and its measure reflects the fact that a taxon will not usually occur throughout the area of its EOO, due to the existence of areas of obviously unsuitable habitat (International... 2001). According to criterion $\mathrm{B} 1$, species with an EOO $<100 \mathrm{~km}^{2},<5,000 \mathrm{~km}^{2}$, and $<20,000 \mathrm{~km}^{2}$ are classified as, respectively, Critically Endangered, Endangered and Vulnerable. Similarly, in B2, species with an AAO $<10 \mathrm{~km}^{2}$, $<500 \mathrm{~km}^{2}$, and $<2,000 \mathrm{~km}^{2}$ follow the same classification. Moreover, based on B2, to be classified as Vulnerable, a species must have an AOO $<2,000 \mathrm{~km}^{2}$ plus at least two of the following:

- Severely fragmented AOO or number of locations $\leq 10$;

- Continuing decline in any of (i) extent of occurrence, (ii) area of occupancy, (iii) area, extent and/or quality of habitat, (iv) number of locations or subpopulations, or (v) number of mature individuals;

- Extreme fluctuations in any of (i) extent of occurrence, (ii) area of occupancy, (iii) number of locations or subpopulations, or (iv) number of mature individuals.

Only one of the criteria needs to be met to list a particular taxon in any of the categories of threat (International... 2011). However, a taxon should be assessed against as many criteria as available data permit, and the listing should be annotated by as many criteria as are applicable for a specific category of threat. No assessment can be accepted for the IUCN Red List as valid unless at least one criterion and any qualifying sub criteria are given and all data used in a listing must be either referenced to a publication that is available in the public domain, or else be made available. Although the criteria for each of the categories of threat are based on quantitative thresholds, the system permits that taxa for which there is very little information can be assessed. We used the best available information in combination with inference and projection to test $E$. taddeii against the five criteria.

$\mathrm{EOO}, \mathrm{AOO}$ and remaining vegetation cover - To calculate the EOO for E. taddeii, we used ArcGis 9.3 software (Environmental... 2008) fed with the coordinates of the 12 known records for the species. We generated a minimum convex polygon using the extension Hawths Tools, with the outermost records as the vertices. The polygon area was calculated using the extension XToolsPro, using the South America Albers Equal Area Conic projection. We then overlapped that 
polygon with the shape file produced by the Atlas dos Remanescentes Florestais da Mata Atlânticas (Fundação... \& Instituto... 2011), in order to evaluate the proportion of remaining original vegetation inside the extent of occurrence for $E$. taddeii, which we believe constitutes the main AOO for the species. We adopted such optimistic approach due to the complete lack of information on others factors which can effectively reduce the species'AOO, such as, environmental variables (e.g. the species' requirements regarding temperature or humidity), biological interactions (e.g. prey availability, impacts of competition or predation), landscape factors (e.g. roost availability or connectivity between forest patches). In fact, its effective AOO could be smaller than that we considered, but a refinement of that area would require more studies on models for the species distribution, and searching for information about the minimum area required for E. taddeii. We researched the literature for data that could be used to confront the species against criterion A, C, D and E. However, considering that E. taddeii was recently described (Miranda et al. 2006) and it is rare among inventories, sources were very scarce. We used data from the same atlas to access the \% of Atlantic forest remaining in each of the 12 municipalities were the species was already recorded, using that information to consider future scenarios of threats and pressures.

\section{Results}

Based on the coordinates of the 12 localities with known records, we calculated the EOO for E. taddeii at $179,221.51 \mathrm{~km}^{2}$ (Figure 1).
The original vegetation in the EOO was severely reduced, with an estimate of only $36 \%$ remaining. That would project a conservative AOO of ca. $64,519.74 \mathrm{~km}^{2}$. However, such forests remnants are extremely fragmented, and frequently surrounded by matrices of large extensions of commercial plantations or urban settlements. The remaining Atlantic Forest in the municipalities varied from $6.1 \%$ in Cerro Azul (PR) to $74.1 \%$ in Iguape (SP), with an average of $21.8 \pm 18.6 \%$. With the exclusion of Iguape and Apiaí $(41.5 \%$ remaining) - exceptions because most of their forests are in a protected area (PETAR)-, the average of remaining forest dropped to $15.3 \pm 7.6 \%$.

Considering there are no data on the population size of E. taddeii, criteria A, C, and E simply could not be evaluated. We did not access criterion D (very small population or very restricted distribution), opting to use data on distribution in the evaluation of criterion B. The calculated EOO (B1) did not qualify E. taddeii in any of the endangered categories. However, for B2, although the species is known in $>10$ locations (currently 12 ), at least in $>83 \%$ of them its AOO is severely fragmented, with not a single forest remnant larger than $10 \mathrm{~km}^{2}$ in those 10 sites. The species has been recorded in three protected areas, however, PEC is remarkably small (337 ha), and the remaining forest cover in the APAED is low, with an average of $11.5 \pm 3.6 \%$ in the 12 municipalities covered by the unit. Moreover, capture records indicated that the species is associated with forests (either primary or in regeneration), with most records in the already

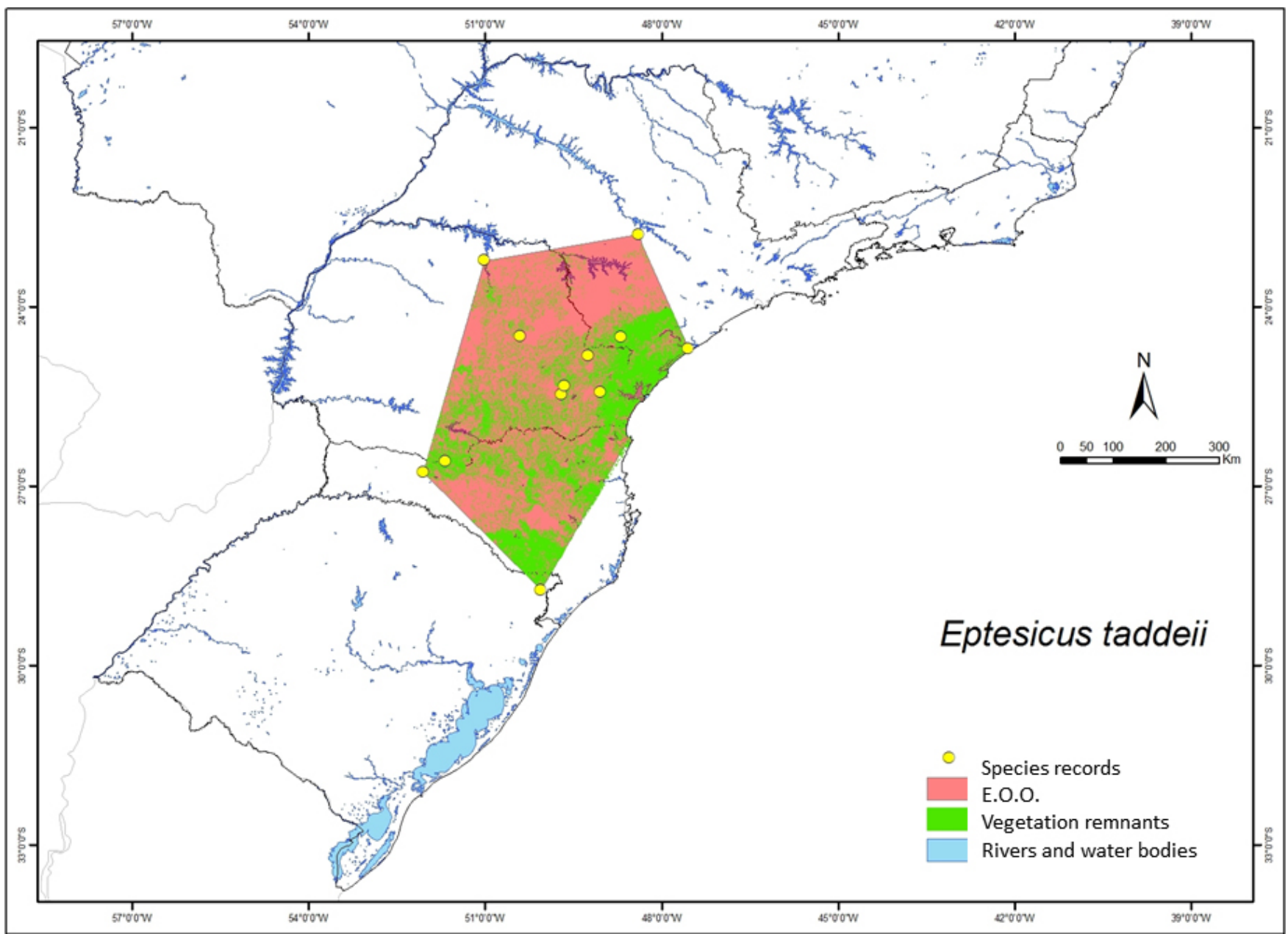

Figure 1. Polygon with the extent of occurrence of the bat Eptesicus taddeii (Vespertilionidae) and the remaining vegetation cover, based on records in 12 localities in the southern Atlantic Forest of Brazil. 
threatened araucaria forest in Southern Brazil. We evaluated that the current state of the $\mathrm{AOO}$ results from degradation in the past, and the pressures and threats experienced by them (agribusiness and real estate speculation) indicates possible future declines in the area, extent and/or quality of the habitat used by the species. Therefore, based on our best judgment, E. taddeii was classified as Vulnerable, by meeting the criteria B2ab(i, ii, iii), i.e., the species has a small area of occupancy, which is severely fragmented, and experiences a continuing decline in its extent of occurrence, area of occupancy, area, extent and quality of habitat.

\section{Discussion}

By clearly presenting the data, criteria and methodology adopted, we provide scientific-based arguments to classify Eptesicus taddeii, a bat species endemic to the Brazilian Atlantic forest, as Vulnerable according to the IUCN Red List. Contrary to what uninformed people may think, the criteria and process to classify species according to its conservation status are evidence-based and benefited when all its phases are transparent and supported by solid data and arguments.

The classification here proposed it is not official and does not conclude the process. Our assessment must be peer reviewed by at least two evaluators assigned by the relevant 'Red List Authority', which in this case is ICMBio. The process can proceed if no inconsistencies are found, leaving ICMBio to promulgate our assessment (together with all other 174 bat species evaluated in the event) which is usually made via a norm (Instrução Normativa) published by the Brazilian Ministério do Meio Ambiente. After its promulgation, comes then what we believe is the most important outcome of the work done, when Red List data are used to guide management of natural resources at multiple scales, including, for example, environmental impact assessments, and in national development policies and legislation.

The classification of species as threatened is a dynamic process and must be constantly updated, facing new data and information (International... 2011). Red-listed species can have its status changed for better or worse and, in fact it, in the ideal world species should not be included in such lists at all. However, the real world has shown that such lists are necessary tools to inform the society on the fragile status of our biodiversity. By taking part in a listing process, and providing the best possible judgment, we, conservation scientists, hope to contribute to change such scenario and improve the decisionmaking process involving biodiversity in our country.

The initiative coordinated by ICMBio to access and evaluates all bat species in Brazil is a large and necessary effort, and the assessment of E. taddeii was part of it. Such effort is noteworthy, considering that the country harbor a very rich bat fauna (currently 175 spp. - Moratelli et al. 2011, Paglia et al. 2011, Nogueira et al. 2012), the knowledge on the Brazilian bats is still very incomplete (Bernard et al. 2011), and considering that bats are not a charismatic group of animals, frequently suffering from misconceptions and misinformation by the general public (Bernard et al. 2012). The evaluation of poorly known species, such as E. taddeii, hopefully will bring more attention to the vulnerability of species that most of the general public doesn't even know to exist.

\section{Acknowledgements}

We would like to thank Instituto Chico Mendes de Conservação da Biodiversidade and its ACADEBio for the invitation to take part in the Oficina de Avaliação do Estado de Conservação de Morcegos Brasileiros. We thank Rosana Subirá, Rita Surrage and Fernanda Voieta for the support and guidance during the event, and Rodrigo Ranulpho da Silva, for providing the data on the EEO, AAO and images. The classification process was greatly improved by the discussions with all the attendees of the workshop and we would like to thank all of them. We thank Daniel Brito for providing useful comments on an earlier version of this manuscript.

\section{References}

AKÇAKAYA, H.R., FERSON, S., BURGMAN, M.A., KEITH, D.A., MACE, G.M. \& TODD, C.R. 2000. Making consistent IUCN classifications under uncertainty. Conserv. Biol. 14:1001-1013. http://dx.doi.org/10.1046/ j.1523-1739.2000.99125.x

BERNARD, E., AGUIAR, L.M.S. \& MACHADO, R.B. 2011. Discovering the Brazilian bat fauna: a task for two centuries? Mammal. Rev. 41(1):23-39. http://dx.doi.org/10.1111/j.1365-2907.2010.00164.x

BERNARD, E., AGUIAR, L.M.S., BRITO, D., CRUZ-NETO, A.P., GREGORIN, R., MACHADO, R.B., OPREA, M., PAGLIA, A.P. \& TAVARES, V.C. 2012. Uma análise de horizontes sobre a conservação de morcegos no Brasil. In Mamíferos do Brasil: Genética, Sistemática, Ecologia e Conservação, vol II (T.R.O. Freitas \& E.M. Vieira, eds.). Sociedade Brasileira de Mastozoologia, Rio de Janeiro, p.19-35.

BUTCHART, S.H.M., STATTERSFIELD, A.J., BAILLIE, J., BENNUN, L.A., STUART, S.N., AKÇAKAYA, H.R., HILTON-TAYLOR, C. \& MACE, G.M. 2005. Using Red List indices to measure progress towards the 2010 target and beyond. Philos. Trans. R. Soc. Lond. B Biol. Sci. 360:255-268. http://dx.doi.org/10.1098/rstb.2004.1583

COLLAR, N.J. 1996. The reasons for Red Data Books. Oryx 30:121-130. http://dx.doi.org/10.1017/S0030605300021505

ENVIRONMENTAL SYSTEMS RESEARCH INSTITUTE - ESRI. 2008. ArcGIS Version 9.3.1. ESRI, Redlands.

FUNDAÇÃO SOS MATA ATLÂNTICA, INSTITUTO NACIONAL DE PESQUISAS ESPACIAIS - INPE. 2011. Atlas dos remanescentes vegetais da Mata Atlântica. http://www.mapas.sosma.org.br (último acesso em 15/11/2012).

HILTON-TAYLOR, C., MACE, G.M., CAPPER, D.R., COLLAR, N.J., STUART, S.N., BIBBY, C.J. POLLOCK, C. \& THOMSEN, J.B. 2000 Assessment mismatches must be sorted out: they leave species at risk. Nature 404:541. http://dx.doi.org/10.1038/35007238

INTERNATIONAL UNION FOR CONSERVATION OF NATURE - IUCN. 2001. IUCN Red List Categories and Criteria: version 3.1. IUCN Species Survival Commission. IUCN, Gland, Switzerland and Cambridge.

INTERNATIONAL UNION FOR CONSERVATION OF NATURE - IUCN. 2011. Guidelines for Using the IUCN Red List Categories and Criteria. version 9.0. Prepared by the Standards and Petitions Subcommittee. http://www.iucnredlist.org/documents/ RedListGuidelines.pdf (ultimo acesso em 15/11/2012).

MARGULES, C.R. \& PRESSEY, R.L. 2000. Systematic conservation planning. Nature 405:243-253. http://dx.doi.org/10.1038/35012251

MILLER, R.M., RODRÍGUEZ, J.P., ANISKOWICZ-FOWLER, T., BAMBARADENIYA, C., BOLES, R., EATON, M.A., GÄRDENFORS, U., KELLER, V., MOLUR, S., WALKER, S. \& POLLOCK, C. 2006. Extinction risk and conservation priorities. Science 313:441. http://dx.doi. org/10.1126/science.313.5786.441a

MILLER, R.M., RODRÍGUEZ, J.P., ANISKOWICZ-FOWLER, T., BAMBARADENIYA, C., BOLES, R., EATON, M.A., GÄRDENFORS, U., KELLER, V., MOLUR, S., WALKER, S. \& POLLOCK, C. 2007. National threatened species listing base on IUCN criteria and regional guidelines: current status and future perspectives. Conserv. Biol. 21:684696. http://dx.doi.org/10.1111/j.1523-1739.2007.00656.x

MIRANDA, J.M.D., BERNARDI, I.P. \& PASSOS, F.C. 2006. A new species of Eptesicus (Mammalia: Chiroptera: Vespertilionidae) from the Atlantic Forest, Brazil. Zootaxa 1383:57-68.

MIRANDA, J.M.D., BERNARDI, I.P., CARVALHO, F. \& PASSOS, F.C. 2010. Novos dados distribucionais do morcego recém descrito Eptesicus taddeii (Vespertilionidae). Chiropt. Neotrop. 16(1):672-674. 
MORATELLI, R., PERACCHI, A.L., DIAS, D. \& OLIVEIRA, J.A. 2011. Geographic variation in South American populations of Myotis nigricans (Schinz, 1821) (Chiroptera, Vespertilionidae), with the description of two new species. Mamm. Biol. 76:592-607. http://dx.doi.org/10.1016/j. mambio.2011.01.003

NOGUEIRA, M.R., LIMA, I.P., PERACCHI, A.L. \& SIMMONS, N.B. 2012. New genus and species of nectar-feeding bat from Atlantic Forest of Southeastern Brazil (Chiroptera: Phyllostomidae: Glossophaginae). Am. Mus. Novit. 3747:1-30. http://dx.doi.org/10.1206/3747.2

PAGLIA, A.P., FONSECA, G.A.B., RYLANDS, A.B., HERRMANN, G., AGUIAR, L.M.S., CHIARELLO, A.G., LEITE, Y.L.R., COSTA, L.P., SICILIANO, S., KIERULFF, M.C.M., MENDES, S.L., TAVARES, V.C., MITTERMEIER, R.A. \& PATTON, J.L. 2011. Lista Anotada dos Mamíferos do Brasil. Occas Pap. Conserv. Biol. 6:1-75.
POSSINGHAM, H.P., ANDELMAN, S.J., BURGMAN, MA., MEDELLÍN, R.A., MASTER, L.L. \& KEITH, D.A. 2002. Limits to the use of threatened species lists. Trends Ecol. Evol. 17:503-507. http://dx.doi. org/10.1016/S0169-5347(02)02614-9

RODRIGUES, A.S.L., AKÇAKAYA, H.R., ANDELMAN, S.J., BAKARR, M.I., BOITANI, L., BROOKS, T.M., CHANSON, J.S., FISHPOOL, L.D.C., FONSECA, G.A.B., GASTON, K.J., HOFFMANN, M., MARQUET, P.A., PILGRIM, J.D., PRESSEY, R.L., SCHIPPER, J., SECHREST, W., STUART, S.N., UNDERHILL, L.G., WALLER, R.W. \& WATTS, M.E. J. 2004. Global gap analysis: Priority regions for expanding the global protected-area network. Bioscience 54:1092-1100. http://dx.doi.org/10.1641/0006-3568(2004)054[1092:GGAPRF]2.0.CO;2

RODRIGUES, A.S., PILGRIM, J.D., LAMOREUX, J.F., HOFFMANN, M. \& BROOKS, T.M. 2006. The value of the IUCN Red list for conservation. Trends Ecol. Evol. 21:71-76. http://dx.doi.org/10.1016/j.tree.2005.10.010 